\title{
Prediction method for ignition delay time of liquid spray combustion in constant volume chamber
}

Ong, Jiun Cai; Pang, Kar Mun; Walther, Jens Honore

Publication date:

2020

Document Version

Peer reviewed version

Link back to DTU Orbit

Citation $(A P A)$ :

Ong, J. C., Pang, K. M., \& Walther, J. H. (2020). Prediction method for ignition delay time of liquid spray combustion in constant volume chamber. Abstract from 73rd Annual Meeting of the American Physical Society, Division of Fluid Dynamics (APS DFD 2020), Chicago, Illinois, United States.

\section{General rights}

Copyright and moral rights for the publications made accessible in the public portal are retained by the authors and/or other copyright owners and it is a condition of accessing publications that users recognise and abide by the legal requirements associated with these rights.

- Users may download and print one copy of any publication from the public portal for the purpose of private study or research.

- You may not further distribute the material or use it for any profit-making activity or commercial gain

- You may freely distribute the URL identifying the publication in the public portal

If you believe that this document breaches copyright please contact us providing details, and we will remove access to the work immediately and investigate your claim. 


\author{
Abstract Submitted \\ for the DFD20 Meeting of \\ The American Physical Society
}

\begin{abstract}
Prediction method for ignition delay time of liquid spray combustion in constant volume chamber ${ }^{1}$ JIUN CAI ONG, Technical University of Denmark, KAR MUN PANG, MAN Energy Solutions, JENS HONORE WALTHER, Technical University of Denmark - A prediction method, known as the Coupled Time Scale (CTS) method, is proposed in the current work to estimate the ignition delay time (IDT) of liquid spray combustion by performing an inert spray simulation and a zero-dimensional (0-D) homogeneous reactor (HR) simulation. The method builds upon the assumption that if the majority of the vapor regions in a spray has composition close to the most reactive mixture fraction, then these regions will have a high probability to undergo high-temperature ignition and ultimately leading to autoignition in spray. The proposed method is applied to estimate high-temperature IDT of $n$-dodecane sprays at three ambient temperatures $\left(T_{\mathrm{am}}\right)$ of 800,900 , and $1000 \mathrm{~K}$, as well as for two nozzle diameters $\left(D_{\mathrm{noz}}\right)$ of 90 and $186 \mu \mathrm{m}$. The fidelity of the proposed CTS method is verified by comparing the predicted IDT against CFD simulated IDT and measured IDT. Comparison of the estimated IDT from the CTS method to measured IDT yields a maximum relative difference of $24 \%$. Meanwhile, a maximum relative difference of $33 \%$ is obtained between the IDT computed from the CTS method and the computed IDT from the large eddy simulations of the associated reacting sprays across the different $T_{\text {am }}$ and $D_{\text {noz }}$

${ }^{1}$ The authors gratefully acknowledge the financial support from the Independent Research Fund Denmark (DFF) and MAN Energy Solutions under the grant number 8022-00143B.
\end{abstract}

Jiun Cai Ong

Technical University of Denmark

Date submitted: 03 Aug 2020

Electronic form version 1.4 